Egyptian Journal of Rabbit Science, 28 (2): 223 -239 (2018)

\title{
EFFECTS OF ADDING LINSEED OIL TO RABBITS DOES' DIETS ON SOME PRODUCTIVE AND REPRODUCTIVE PERFORMANCE TRAITS
}

\author{
A.El.M.I. El-Desoky ${ }^{1}$; M.M. El-Deeb ${ }^{1} ;$ Y. Elseady ${ }^{2}$ A.M. Alazab ${ }^{1}$ and \\ M.A. El-Sawy ${ }^{1}$ \\ ${ }^{1}$ Anim. Prod. Res. Inst., Agric. Res. Center, Dokki, Giza, Egypt. \\ ${ }^{2}$ Department of Physiology, Faculty of Veterinary Medicine, Mansoura \\ University, Mansoura, Egypt.
}

Twenty mature New-Zealand White (NZW) rabbits does (about 5-6 months of age and $2.75-3.00 \mathrm{~kg}$ of life body weight) were used in the present study. The study aimed to test three levels of linseed oil with soluble $(1.5 \%, 3.0 \%$ and $4.5 \%)$ as feed supplementation to basal diet on some productive and reproductive performance of rabbit does. Some blood parameters as well as the economic efficiency of using these levels were also studied.

The obtained results show that $3.0 \%$ linseed oil supplementation significantly decreased $(P \leq 0.05)$ the number of services per conception (NSC), days open (DO) and kidding interval (KI) without affecting the length of gestation period (GPL) compared to those of the control group.

No significant effect on litter size $(L S)$ as well as daily weight gain (DWG) from birth till 35 days of age due to different levels of linseed oil supplementation compared to those of the control group. While, supplementation with $4.5 \%$ linseed oil significantly improved $(P \leq 0.05)$ litter weight $(L W)$ and mean bunny weight $(M B W)$ of $N Z W$, does. Although there were no significant differences among the experimental groups in mortality rate $(M R \%)$ during the first two periods (birth-21 and 21-35 days of age), the 3.0\% linseed oil treatment gave the lowest $(P \leq 0.05) M R \%$.

Blood parameters showed that linseed oil supplementation groups had the highest $(P \leq 0.05)$ total protein $(T P)$ level recorded after the first parity followed by those recorded at the end of the experiment and after the second parity, respectively. The level of globulin (Glob.) was increased but without significant difference after the first parity and the albumin (Alb.) concentrations gave its high 
values in the $3.0 \%$ oil supplementation group. The highest total lipids (TL) obtained with $1.5 \%$ and $4.5 \%$ oil supplementation groups without significant differences between them, but such differences were significant with the other two experimental groups (control and $3.0 \%$ oil supplementation). The supplementation of diets with linseed oil generally tended to decrease cholesterol level compared to that of the control. The control group recorded the highest $(P \leq 0.05)$ high density lipids $(H D L)$ values compared to other groups of linseed oil supplementation which were insignificantly differed. Supplementing does' diets with linseed oil resulted to significantly increase triglycerides $(T G)(P \leq 0.05)$ especially after the first parity and at the end of the experiment. The 3.0\% linseed oil supplementation recorded the lowest $(P \leq 0.05) T G$ value among the other two supplemented groups at the end of the experiment.

Conclusively, it could be concluded that supplementing diets of rabbit' does with $3.0 \%$ linseed oil would impact positively on dams reproductive, productive traits and their health status. From economic point of view, the addition of oil as a source of Omega-3polyunsaturated fatty acids decreased average feed consumed per parity by about $13 \%$ and improved relative economic efficiency by about $40 \%$.

Keywords: Linseed oil, rabbits, feed intake, productive \& reproductive performance, blood characteristics, economic efficiency.

In recent decades, human health concern took place because of the century diseases spread all over the world, so that a demand increased on producing healthy meat (meat with low saturated fatty acids "FAs" and high unsaturated Fatty acid levels).

In (2000) Simopoulos reported that Omega-3-polyunsaturated fatty acids ( $\Omega$-3-PUFA) plays a vital role in human nutrition since they help to reduce the incidence of coronary artery diseases, hypertension and diabetes and certain inflammatory diseases as arthritis and dermatitis. So that, rabbit meat may be suitable to produce specific functional foods because of it is characterized by its content of fatty acid profile, vitamin and minerals which could be further enriched via feeding (Suraï, 2002; Marounek et al., 2009 and DalleZotte and Szendrö, 2011). Rabbits like other monogastric animals are able to incorporate dietary fatty acids into adipose tissue and 
intramuscular fats, thus making it possible to modify the fatty acids profile of rabbits' meat through the planned use of unsaturated dietary fat sources (Dalle Zotte, 2002). Baucells et al. (2000) stated that enrichment of $\Omega$-3PUFA in rabbit meats could be a right way to ensure an adequate supply of $\Omega$-3-PUFA for the population and this can be reached by adding common sources of $\Omega$-3-PUFA such as Linseed oil to the rabbit diet.

In (2006) Hernández and Gondret reported that Linseed oil is common feed ingredients used to increase meat $\Omega$-3-PUFA in rabbits. Moreover, as reported by Bielanski and Kowalska (2008) several studies recorded a favorable effect on the composition of the lipid fraction of rabbit meat, causing a significant decrease in total saturated fatty acids (SFA) and an increase in polyunsaturated fatty acids ( $\Omega$-3-PUFA) when Linseed oil added to rabbit diets. Also, Popa et al. (2012) reported that linseed oil contains $6.58 \%$ 16:0 palmitic, $4.43 \%$ 18:0 stearic, $18.51 \%$ 18:1 Oleic, 17.25\% 18:2 Linoleic and 53.21\% 18:3 Linolenic unsaturated fatty acids.

In (2009) Cavani et al. reported that the administration of enriched diets during the last two weeks of fattening (rearing) is sufficient to increase the polyunsaturated fatty acids $(\Omega-3$-PUFA) content of the meat and this approach may reduce costs in comparison to a longer treatment.

It is well known that fat in the diets improves energy status of feeds thus can influence reproduction. In this concern, Mattos et al. (2000) explained that positive reproduction using diets supplemented with fats can take place by altering both ovarian follicles and corpus luteum function through increasing precursors for the synthesis of reproductive hormones such as steroids and prostaglandin.

Elkomy and El-Speiy (2015) concluded that replacement of the prostaglandin-F2-alpha (PGF2 $\alpha$ ) injection by oral administration at the rate of $3 \mathrm{ml} /$ doe/day of Sunflower or Linseed oils to old does improved sexual hormone synthesis and secretion, litter size at birth by $21.9 \%$ and bunny body weight at birth by $22 \%$ compared to the control group.

Therefore, the aim of the present study was to find out the effect of supplementing different levels of linseed oil in the diets of New-Zealand rabbits does as a source of Omega-3-polyunsaturated fatty acids ( $\Omega$-3PUFA) on some productive and reproductive traits and its reflection on some blood parameters. Economic efficiency of feeding these supplementations levels compared to that of the control group was also studied. 


\section{MATERIALS AND METHODS}

The experimental work was carried out in a special rabbit production farm at Dekkrns District, Dakahlia Governorate, Egypt. three levels of linseed oil with soluble $(1.5 \%, 3.0 \%$ and $4.5 \%)$ as feed supplementations were incorporated to basal diets. The system provided animals with fresh water and diets which were offered ad libitum all time over the experimental period. The experimental diets were offered on pelleted form which formulated in the farm from the available ingredients to cover the nutrient requirements of rabbits as recommended by NRC (1977) as shown in Table 1.

\section{Animals and management:}

Twenty mature New-Zealand White does (5-6 months of age and 2.75$3.00 \mathrm{~kg}$ life body weight) were used in the present study. The experimental animals were divided between four groups ( 5 mature does each). Each group of rabbits was fed one of the four experimental diets which contained linseed oil $(0,1.5,3.0$ and $4.5 \%)$. The rabbits were separately housed in individual wired-cages $(50 \times 50 \times 35 \mathrm{~cm})$.

Rabbits were kept under similar management system. Cages and nest boxes were cleaned and disinfected regularly before each kindling. Light in their houses was allowed 12-14 hours per day during the period of the study, urine and faces dropped from the cages on the floor were cleaned every day in the morning.

Each doe was transferred to the cage of buck assigned for mating and returned back to her own cage after being mated. Each doe was palpated 10 days thereafter to determine pregnancy and those failed to conceive were returned to the same mated buck. On $27^{\text {th }}$ day of pregnancy, the nest boxes were supplied with wooden straw to help the doe in preparing a worm suitable comfortable nest for the bunnies of her litter. Within 12 hours after kindling, litter were checked and date of birth, number of kits, stillbirth removed and weight of kits were recorded. Afterwards, litters were examined each morning during the suckling period and the dead ones were recorded and removed from the nest. Young rabbits were weaned at five weeks of age (35 day) and transferred to the progeny cages with group of five rabbits per cage.

\section{Does' reproductive traits:}

Reproductive performance of doe rabbits including number of services per conception (NSC), days open (DO, interval from kindling to next conception), gestation period length (GPL) and kindling interval (KI) were calculated. 
Table (1): The composition and calculated chemical analysis of the tested diets fed to rabbits during the experimental period.

\begin{tabular}{|c|c|c|c|c|}
\hline Ingredients & Control & $\begin{array}{c}\text { Linseed oil } \\
1.5 \%\end{array}$ & $\begin{array}{c}\text { Linseed oil } \\
3 \%\end{array}$ & $\begin{array}{c}\text { Linseed oil } \\
4.5 \%\end{array}$ \\
\hline Yellow corn & 7 & 5.5 & 4 & 2.5 \\
\hline Barley & 18 & 18 & 18 & 18 \\
\hline Wheat bran & 17 & 17 & 17 & 17 \\
\hline Soybean meal (44\%) & 8 & 8 & 8 & 8 \\
\hline Sunflower meal & 15 & 15 & 15 & 15 \\
\hline Alfalfa hay & 30 & 30 & 30 & 30 \\
\hline Molasses & 2 & 2 & 2 & 2 \\
\hline D-Calcium Phosphate & 1.2 & 1.2 & 1.2 & 1.2 \\
\hline Lime stone & 1 & 1 & 1 & 1 \\
\hline Salt & 0.4 & 0.4 & 0.4 & 0.4 \\
\hline Premix $^{1}$ & 0.3 & 0.3 & 0.3 & 0.3 \\
\hline Methionine & 0.1 & 0.1 & 0.1 & 0.1 \\
\hline Linseed oil & 0 & 1.5 & 3.0 & 4.5 \\
\hline Total & 100 & 100 & 100 & 100 \\
\hline \multicolumn{5}{|c|}{ Calculated chemical analysis of diets on DM basis (\%) ${ }^{2}$} \\
\hline $\mathrm{ME}(\mathrm{Kcal} / \mathrm{Kg})$ & 2731 & 2800 & 2869 & 2938 \\
\hline $\mathrm{CP}$ & 18.80 & 18.67 & 18.54 & 18.41 \\
\hline $\mathrm{CF}$ & 14.63 & 14.60 & 14.57 & 14.54 \\
\hline $\mathrm{EE}$ & 2.46 & 3.89 & 5.32 & 6.64 \\
\hline $\mathrm{Ca}$ & 1.20 & 1.20 & 1.20 & 1.20 \\
\hline $\begin{array}{l}\text { Available } \\
\text { Phosphorus }\end{array}$ & 0.46 & 0.46 & 0.46 & 0.46 \\
\hline Lysine & 0.81 & 0.81 & 0.81 & 0.80 \\
\hline Methionine & 0.41 & 0.41 & 0.41 & 0.41 \\
\hline Methionine+Cystine & 0.71 & 0.71 & 0.70 & 0.70 \\
\hline Threonine & 0.59 & 0.58 & 0.57 & 0.57 \\
\hline Tryptophan & 0.26 & 0.26 & 0.26 & 0.25 \\
\hline
\end{tabular}

${ }^{1}$ Each $1 \mathrm{Kg}$ of the Premix contains: Vitamin A 2 MIU, Vit. $\mathrm{D}_{3} 150000 \mathrm{IU}$, Vit. E $8.33 \mathrm{~g}$, Vit. K 0.33 g, Vit. B 1 g, Vit.B 1.09 g, Vit.B ${ }_{6} 0.33$ g, Vit.B 8.33 g, Vit. B $121.7 \mathrm{mg}$, Pantothenic acid $3.33 \mathrm{~g}$, Folic acid $0.83 \mathrm{~g}$, Biotin $33 \mathrm{mg}$, Choline chloride $20 \mathrm{~g}, \mathrm{Mg}$ $66.79 \mathrm{~g}, \mathrm{Zn} 11.79 \mathrm{~g}$, Fe $12.5 \mathrm{~g}$, Cu $0.5 \mathrm{~g}$, I $0.3 \mathrm{~g}$, Se $16.6 \mathrm{mg}$, Co $1.33 \mathrm{mg}$ and carrier $\mathrm{CaCO}_{3}$ up to $1000 \mathrm{~g}$.

${ }^{2}$ According to NRC (1977).

\section{Does' productive traits:}

Litter size (LS) as well as litter weights (LW) were recorded at 21 days and 35 days of age. Mean bunny weight (MBW) was measured at birth, 21 
days and 35 days of age and thereafter daily weight gain (DWG) calculated for the periods of from birth till 21 days, from 21 till 35 days and for the whole period from birth till weaning (at 35 days) age. Mortality rate (MR) as one of the sensitive parameters related to the economical return of production was also recorded in the present investigation at birth, 21 days (from birth up to 21 days of age) and 35 days (from birth up to 35 days of age).

\section{Serum biochemical studies:}

Some biochemical parameters in serum of does through three times (after the first parity, after the second parity and at the end of experimental period) were investigated in the collected samples in a heparonized tubes foreach rabbit.Samples placed immediatelyonice and plasma were obtained by centrifugation at $4000 \mathrm{rpm}$ for $20 \mathrm{~min}$. and werestoredat $-20^{\circ} \mathrm{C}$ until analysis .Plasma samples were analyzed forthe levels of total protein (TP), globulin (Glob.), albumin (Alb.), total lipids (TL), cholesterol, high density lipids (HDL) and tri-glycerides (TG) calorimetrically using commercial kits (Diamond Diagnostics, Egypt) according to the procedure outlined by the manufacturer.

\section{Economic Efficiency:}

To evaluate the economic efficiency of using the experimental feed additives in does' rabbit diets, total feed consumption/dam and feed consumption for does with their litter were recorded. Total weight rabbits/dam, average of parity/dam, average of feed consumed ( $\mathrm{Kg} / \mathrm{dam} /$ parity) and average weight rabbits/dam/parity used to calculate economic efficiency and relative economic efficiency depending on the market prices for both costs and return, during the experimental period. Economic Efficiency (E.E) was calculated as follows:

Total feed cost/dam (L.E) = Total feed intake $(\mathrm{Kg}) \times$ price/kg feed (L.E).

Total return/dam (L.E) = Total weight rabbits/dam $(\mathrm{kg}) \times$ price/kg live body weight (L.E)

Net return/ dam (L.E) $=$ Total return/dam (L.E) - Total feed cost/dam (L.E)

Economic Efficiency (E.E) $=$ Net return/dam (L.E) $/$ Total feed cost/dam (L.E)

\section{Statistical analysis:}

Data were statistically analyzed by Using Computer Program of SAS (2000) using the general linear models (GLM). Significance among treatment means were tested at $(\mathrm{P} \leq 0.05)$ using Duncan's New Multiple Rang Test (Duncan, 1955). 


\section{RESULTS AND DISCUSSION}

\section{Reproductive traits:}

The obtained results for the effect of adding linseed oil to diets of does on number of services per conception (NSC), gestation period length (GPL), days open (DO, interval from kindling to next conception) and kindling interval (KI) were recorded in Table (2).

Results indicates clearly that using linseed oil significantly decreased NSC and the best level of supplementation for this character was $3.0 \%$ compared to the control one and the other two supplementations levels. On the other hand, gestation period length (GPL) did not show any significant influence due to the supplementation compared to the control group. Does rabbit received $3.0 \%$ linseed oil supplementation in their diets recorded the lowest $(\mathrm{P} \leq 0.05) \mathrm{DO}$, while those received $1.5 \%$ gave the longest $(\mathrm{P} \leq 0.05)$ period of DO. The KI trait showed the same trend for DO since it was the shortest $(\mathrm{P} \leq 0.05)$ with $3.0 \%$ linseed oil supplementation and the longest $(\mathrm{P} \leq 0.05)$ with $1.5 \%$ linseed oil supplementation.

The obtained results supported by findings of Elkomy and El-Speiy (2015) who found that fertility rate improved in rabbits' does treated with a synthetic prostaglandin-F2 $\alpha+$ equine Chorionic Gonadotropin or with prostaglandin precursor (Sunflower or Linseed) + PMGs and conception rate as well in comparison to the PMGs alone.

Such trend and findings explained by Mattos et al. (2000) who stated that positive reproduction is the reflection of using diets supplemented with fats by altering both ovarian follicles and corpus luteum function through increasing precursors of synthesis for reproductive hormones (steroids and prostaglandin).

Generally, the fluctuation in the results of the reproductive traits can occur on the bases of the fact that although essential oils claimed to being digestive enhancers, having antimicrobial activity and promote general health. Hippenstiel et al. (2011) and Bozkurt et al. (2014) reported that studies still lack in quantification of active components and explaining their mode of action and accordingly standardization will be imprecise.

\section{Productive traits:}

The obtained results for the effect of incorporating different levels of linseed oil to diets of does on litter size (LS), litter weight (LW), mean bunny weight (MBW), bunny daily weight gain (DWG) and mortality rate(MR) are presented in Table 3. The LS did not show any significant changes during the 
Table (2): Effect of adding different levels of linseed oil to rabbit does diets on some reproductive traits.

\begin{tabular}{|l|c|c|c|c|c|}
\hline \multirow{2}{*}{$\begin{array}{c}\text { Reproductive } \\
\text { parameters }\end{array}$} & \multicolumn{5}{|c|}{ Treatments groups } \\
\cline { 2 - 6 } & Control & $\begin{array}{c}\text { Linseed } \\
\text { oil 1.5\% }\end{array}$ & $\begin{array}{c}\text { Linseed } \\
\text { oil 3\% }\end{array}$ & $\begin{array}{c}\text { Linseed } \\
\text { oil 4.5\% }\end{array}$ & $\begin{array}{c} \pm \text { SE } \\
\text { mean }\end{array}$ \\
\hline NSC & $2.75^{\mathrm{a}}$ & $1.76^{\mathrm{b}}$ & $1.40^{\mathrm{b}}$ & $1.66^{\mathrm{b}}$ & 1.12 \\
\hline GPL & 30.16 & 30.38 & 30.33 & 30.41 & 0.47 \\
\hline DO & $24.00^{\mathrm{ab}}$ & $26.37^{\mathrm{a}}$ & $12.80^{\mathrm{b}}$ & $15.57^{\mathrm{ab}}$ & 11.24 \\
\hline KI & $54.14^{\mathrm{ab}}$ & $56.62^{\mathrm{a}}$ & $43.10^{\mathrm{b}}$ & $45.85^{\mathrm{ab}}$ & 11.19 \\
\hline
\end{tabular}

${ }^{\mathrm{a}, \mathrm{b}}$ Means in the same raw bearing different superscript are significantly different $(\mathrm{P} \leq 0.05)$.

Table (3): Effect of adding different levels of linseed oil to rabbit does diets on some productive traits.

\begin{tabular}{|c|c|c|c|c|c|c|}
\hline \multirow{2}{*}{\multicolumn{2}{|c|}{$\begin{array}{c}\text { Reproductive } \\
\text { parameters }\end{array}$}} & \multicolumn{5}{|c|}{ Treatments groups } \\
\hline & & \multirow{2}{*}{$\begin{array}{c}\text { Control } \\
6.83\end{array}$} & \multirow{2}{*}{$\begin{array}{c}\begin{array}{c}\text { Linseed } \\
\text { oil 1.5\% }\end{array} \\
6.84\end{array}$} & \multirow{2}{*}{$\begin{array}{c}\begin{array}{c}\text { Linseed } \\
\text { oil 3\% }\end{array} \\
7.73 \\
\end{array}$} & \multirow{2}{*}{$\begin{array}{c}\begin{array}{c}\text { Linseed } \\
\text { oil } 4.5 \%\end{array} \\
7.58\end{array}$} & \multirow{2}{*}{$\begin{array}{c}\begin{array}{c} \pm \mathrm{SE} \\
\text { mean }\end{array} \\
1.25\end{array}$} \\
\hline \multirow{3}{*}{$\mathbf{L S}$} & At birth & & & & & \\
\hline & 21 days & 6.33 & 6.69 & 7.20 & 7.08 & 1.16 \\
\hline & 35 days & 6.25 & 6.46 & 6.80 & 7.08 & 1.23 \\
\hline \multirow{3}{*}{$\begin{array}{c}\mathbf{L W} \\
(\mathrm{g})\end{array}$} & At birth & $365.41^{\mathrm{b}}$ & $360.38^{\mathrm{b}}$ & $411.00^{\mathrm{ab}}$ & $428.75^{\mathrm{a}}$ & 63.97 \\
\hline & 21 days & 2012.50 & 2079.61 & 2264.33 & 2294.58 & 363.91 \\
\hline & 35 days & 4847.08 & 4839.23 & 5276.00 & 5443.75 & 840.42 \\
\hline \multirow{3}{*}{$\begin{array}{c}\text { MBW } \\
(\mathrm{g})\end{array}$} & At birth & $54.20^{\mathrm{ab}}$ & $52.61^{b}$ & $53.26^{\mathrm{ab}}$ & $56.66^{\mathrm{a}}$ & 4.27 \\
\hline & 21 days & 322.75 & 311.92 & 315.33 & 324.58 & 31.26 \\
\hline & 35 days & 784.91 & 755.65 & 782.06 & 770.00 & 65.87 \\
\hline \multirow{3}{*}{$\begin{array}{c}\text { DWG } \\
(\mathrm{g})\end{array}$} & 0-21 days & 12.78 & 12.34 & 12.48 & 12.75 & 1.38 \\
\hline & 21-35 days & 33.01 & 31.69 & 33.33 & 31.81 & 4.00 \\
\hline & 0-35 days & 20.87 & 20.08 & 20.82 & 20.38 & 1.83 \\
\hline \multirow{3}{*}{$\begin{array}{l}\text { MR } \\
(\%)\end{array}$} & 0-21 days & 1.00 & 1.00 & 1.00 & 1.00 & 0.00 \\
\hline & 21-35 days & 0.96 & 1.00 & 0.94 & 0.94 & 0.19 \\
\hline & 0-35 days & $0.93^{\mathrm{ab}}$ & $1.00^{\mathrm{a}}$ & $0.85^{\mathrm{b}}$ & $0.94^{\mathrm{ab}}$ & 0.24 \\
\hline
\end{tabular}

${ }^{a, b}$ Means in the same raw bearing different superscript are significantly different $(\mathrm{P} \leq 0.05)$.

three experimental recoding times from birth till 35 days of age compared with those of the control. On the other hand, LW showed significant $(\mathrm{P} \leq 0.05)$ increase with using $4.5 \%$ linseed oil at birth time compared to those in the group of $1.5 \%$ and the control ones. At birth time only the heaviest $(\mathrm{P} \leq 0.05) \mathrm{MBW}$ obtained when diets supplemented with $4.5 \%$ oil, while the lowest $(\mathrm{P} \leq 0.05)$ value was recorded with using $1.5 \%$ oil. Does of the $3.0 \%$ oil and control groups recorded the intermediate value compared with those 
of $1.5 \%$ and $4.5 \%$ linseed oil supplementation but without significant differences either at birth or during the two recording times.

During the periods from birth till 21 days, from 21 till 35 and from birth till 35 days of age, DWG did not show any significant $(\mathrm{P} \leq 0.05)$ differences due to linseed oil supplementation to the dams' diets. It is worth to mention that during the whole period from birth till 35 days of age, the $\mathrm{MR} \%$ gave the lowest $(\mathrm{P} \leq 0.05)$ value in the $3.0 \%$ oil supplementation group, while the highest $(\mathrm{P} \leq 0.05)$ value recorded with the $1.5 \%$ oil supplementation group. The recorded values for the control group and $4.5 \%$ oil supplementation ones did not significantly differ compared with the other two treatment groups. On the other hand, no significant effect was noticed in MR\% during the two periods from birth till 21 days of age and from 21 days till 35 days of age.

The obtained results in the present study clearly indicates that the use of $3.0 \%$ linseed oil improved the productive traits of does compared to the other two supplementation rates (1.5 and $4.5 \%)$ and the control ones. These results are in harmony with those recorded by Elkomy and El-Speiy (2015) who found that replacement of the prostaglandin-F2-alpha (PGF2 $\alpha$ ) injection by oral administration at the rate of $3 \mathrm{ml} /$ doe/day of Linseed oil to old does improved litter size at birth by $21.9 \%$ and bunny body weight at birth by $22 \%$ compared to the control group. Similar results of daily weight gain for the insignificant effect of linseed oil supplementation obtained herein are reported by Zeweil et al. (2016). Regarding the reduction in MR\%, it can be supported by McKeegan and Sturmey (2012) who stated that the lipids stored within the oocyte and early embryo represents an important source of energy for the early embryo. Moreover, Kowalska (2008) found that the female rabbits fed a complete diet supplemented with fish oil had a quantitatively and qualitatively better milk fat content, higher fertility prolificacy values, and higher body weight of young rabbits at birth. These findings supported the obtained results in the present investigation in terms of increased litter size, fertility and higher body weight at birth.

The results obtained in this study are in general agreement with other studies showing that diets contained high n-3 PUFA did not significantly influence productive performances in rabbits as discussed and reviewed by Trebušak et al. (2011). On the other hand, Szendrö et al. (2012) reported that body weight gain, body weight, feed intake and feed conversion were not affected by dietary treatment. They also found that mortality was lower in the group received linseed oil, vitamin E and selenium for one week 
during the finishing period compared with that of the control group by $13.4 \%$ and the other two experimental groups (being 5.6 and $11.1 \%$, resp.). Moreover, Rodriguez et al. (2017) reported that the control diet (contained $4.59 \mathrm{~g}$ of $\mathrm{n}-3$ per $100 \mathrm{~g}$ of total fatty acids "FA") with $14.9 \mathrm{~g}$ of $\mathrm{n}-3$ per 100 g FA did not make differences $(\mathrm{P}>0.05)$ between groups in average daily feed intake, average daily gain and gain: feed ratio during the growing period of rabbits.

In general, the improvement in body weight gain and health status of animals can be attributed to supplementation of diets with essential oils which are often supposed to change flavor and palatability of feeds, thus increasing voluntary feed intake. In this concern, Zeng et al. (2015) reported that "herbs and their constituent essential oils are often supposed to improve flavor and indirectly palatability of feeds, thus increasing voluntary feed intake which, in turn, results in improved body weight gain and feed conversion ratio".

\section{Serum biochemical studies:}

Data in Table (4) presents for the reflection of using linseed oil supplementation in does' rabbit diets on total protein (TP), globulin (Glob.), albumin (Alb.), total lipids (TL), cholesterol, high density lipids (HDL) and tri-glycerides (TG) in their serum. It is worth mentioning that TP increased with sampling time advancement recording the highest $(\mathrm{P} \leq 0.05)$ value at the end of the experiment in the control group. While, linseed oil supplementation group recorded the highest $(\mathrm{P} \leq 0.05) \mathrm{TP}$ value at the first sampling time followed by those recorded at the end of the experiment and second sampling time, respectively. The value of Glob. was increased but without significant at first sampling time due to oil supplementations, while significant differences noticed with using $1.5 \%$ oil supplementation at second sampling time and at end of the experiment of sampling times. The Alb. concentrations gave its high values in the 3.0\% oil supplementation group. The highest TL obtained with $1.5 \%$ and $4.5 \%$ oil supplementation groups without significant differences between them, but such differences were significant with the other two experimental groups (control and 3.0\% oil supplementation) which recorded the lowest values especially at the second and third sampling times. Cholesterol showed general trend to increase with sampling time advancement, but the supplementation of diets with linseed oil generally tended to decrease cholesterol level compared to the control. The $3.0 \%$ oil supplementation was the best treatment recorded the lowest cholesterol level. The control 
Table (4): Effect of adding different levels of linseed oil to rabbit does diets on serum some biochemical parameters.

\begin{tabular}{|c|c|c|c|c|c|c|}
\hline \multirow[b]{2}{*}{$\begin{array}{c}\text { Reproductive } \\
\text { parameters }\end{array}$} & \multirow[b]{2}{*}{ Time } & \multicolumn{5}{|c|}{ Treatments } \\
\hline & & Control & $\begin{array}{l}\text { Linseed } \\
\text { oil } 1.5 \%\end{array}$ & $\begin{array}{c}\text { Linseed } \\
\text { oil 3\% }\end{array}$ & $\begin{array}{l}\text { Linseed } \\
\text { oil } 4.5 \%\end{array}$ & $\begin{array}{c} \pm \mathrm{SE} \\
\text { mean }\end{array}$ \\
\hline \multirow{3}{*}{$\mathbf{T P}(\mathrm{gm} / \mathrm{dl})$} & $1^{\mathrm{st}}$ & $5.99^{b}$ & $7.33^{\mathrm{a}}$ & $7.16^{\mathrm{a}}$ & $6.70^{\mathrm{ab}}$ & 0.320 \\
\hline & $2^{\text {nd }}$ & $5.96^{\mathrm{b}}$ & $7.50^{\mathrm{a}}$ & $6.16^{\mathrm{b}}$ & $6.00^{\mathrm{b}}$ & 0.174 \\
\hline & $3^{\text {rd }}$ & $7.03^{\mathrm{a}}$ & $6.03^{\mathrm{b}}$ & $6.33^{\mathrm{ab}}$ & $6.24^{\mathrm{ab}}$ & 0.145 \\
\hline \multirow{3}{*}{ Glob. $(\mathrm{gm} / \mathrm{dl})$} & $1^{\mathrm{st}}$ & 3.89 & 4.46 & 4.06 & 3.70 & 0.290 \\
\hline & $2^{\text {nd }}$ & $3.33^{\mathrm{b}}$ & $4.33^{\mathrm{a}}$ & $2.96^{\mathrm{b}}$ & $2.90^{\mathrm{b}}$ & 0.182 \\
\hline & $3^{\text {rd }}$ & $4.20^{\mathrm{a}}$ & $3.16^{\mathrm{b}}$ & $2.73^{\mathrm{b}}$ & $2.97^{\mathrm{b}}$ & 0.143 \\
\hline \multirow{3}{*}{ Alb. $(\mathrm{gm} / \mathrm{dl})$} & $1^{\text {st }}$ & $2.10^{\mathrm{c}}$ & $2.86^{\mathrm{b}}$ & $3.10^{\mathrm{a}}$ & $3.00^{\mathrm{ab}}$ & 0.127 \\
\hline & $2^{\text {nd }}$ & $2.63^{\mathrm{c}}$ & $3.16^{\mathrm{ab}}$ & $3.20^{\mathrm{a}}$ & $3.10^{\mathrm{b}}$ & 0.097 \\
\hline & $3^{\text {rd }}$ & $2.83^{\mathrm{c}}$ & $2.86^{\mathrm{b}}$ & $3.60^{\mathrm{a}}$ & $3.26^{\mathrm{a}}$ & 0.088 \\
\hline \multirow{3}{*}{ TL $(\mathrm{mg} / \mathrm{dl})$} & $1^{\mathrm{st}}$ & $926.66^{c}$ & $975.00^{\mathrm{ab}}$ & $951.66^{\mathrm{ab}}$ & $1158.33^{\mathrm{a}}$ & 50.96 \\
\hline & $2^{\text {nd }}$ & $1008.33^{b}$ & $1266.66^{\mathrm{a}}$ & $975.00^{b}$ & $1283.33^{\mathrm{a}}$ & 38.42 \\
\hline & $3^{\text {rd }}$ & $951.66^{b}$ & $1316.66^{\mathrm{a}}$ & $958.33^{b}$ & $1308.33^{\mathrm{a}}$ & 56.04 \\
\hline \multirow{3}{*}{$\begin{array}{l}\text { Cholesterol } \\
(\mathrm{mg} / \mathrm{dl})\end{array}$} & $1^{\mathrm{st}}$ & $41.66^{\mathrm{a}}$ & $32.33^{\mathrm{b}}$ & $33.33^{b}$ & $35.33^{\mathrm{ab}}$ & 2.49 \\
\hline & $2^{\text {nd }}$ & $51.00^{\mathrm{b}}$ & $71.00^{\mathrm{a}}$ & $32.60^{c}$ & $36.00^{c}$ & 1.85 \\
\hline & $3^{\text {rd }}$ & $50.00^{\mathrm{b}}$ & $51.00^{\mathrm{b}}$ & $69.33^{\mathrm{a}}$ & $50.00^{b}$ & 1.60 \\
\hline \multirow{3}{*}{ HDL (mg/dl) } & $1^{\text {st }}$ & $120.00^{\mathrm{a}}$ & $64.44^{\mathrm{bc}}$ & $65.33^{b}$ & $57.88^{\text {bc }}$ & 1.07 \\
\hline & $2^{\text {nd }}$ & $111.66^{\mathrm{a}}$ & $65.80^{\mathrm{b}}$ & $70.36^{b}$ & $66.40^{b}$ & 1.67 \\
\hline & $3^{\text {rd }}$ & $91.66^{\mathrm{a}}$ & $64.50^{\mathrm{b}}$ & $66.56^{\mathrm{b}}$ & $65.30^{\mathrm{b}}$ & 2.10 \\
\hline \multirow{3}{*}{ TG (mg/dl) } & $1^{\mathrm{st}}$ & $26.10^{d}$ & $57.62^{b}$ & $67.89^{\mathrm{a}}$ & $44.03^{c}$ & 2.39 \\
\hline & $2^{\text {nd }}$ & $52.21^{\mathrm{ab}}$ & $62.66^{\mathrm{b}}$ & $72.00^{\mathrm{a}}$ & $55.86^{\mathrm{c}}$ & 1.48 \\
\hline & $3^{\text {rd }}$ & $38.28^{\mathrm{d}}$ & $83.40^{\mathrm{a}}$ & $42.03^{\mathrm{c}}$ & $76.31^{b}$ & 2.48 \\
\hline
\end{tabular}

${ }^{\mathrm{a}, \mathrm{b}}$ Means in the same raw bearing different superscript are significantly different $(\mathrm{P} \leq 0.05)$.

group recorded the highest $(\mathrm{P} \leq 0.05) \mathrm{HDL}$ values compared to other groups fed linseed oil supplementation which recorded lower values without significant differences among them. Supplementing does' diets with linseed oil significantly increased $\mathrm{TG}(\mathrm{P} \leq 0.05)$ especially at first and last sampling times. The 3.0\% linseed oil supplementation recorded the lowest $(\mathrm{P} \leq 0.05) \mathrm{TG}$ value among the other two supplemented groups end period of the experiment.

Eid et al. (2010) found that serum cholesterol levels as well as triglycerides were significantly decreased in rabbits fed $2 \%$ linseed oil relative to control diet. On the other hand, high density lipoprotein cholesterol (HDL) values were significantly $(\mathrm{P} \leq 0.05)$ increased by supplementing $2 \%$ linseed oil.

The obtained results came on line with those obtained by Kemin et al. (2008) on mice. In this concern, Ikeda et al. (2001) explained the 
reduction in plasma triglyceride concentrations by $\Omega-3$ fatty acids achieved through reduced endogenous very low-density lipoprotein production. Moreover, Salama (2011) reported that plasma cholesterol and triglycerides concentrations were significantly decreased in rabbits fed diet supplemented with $2 \%$ linseed oil compared to the control diet. On the other hand, values of HDL were significantly $(\mathrm{P} \leq 0.05)$ increased by supplementing $2 \%$ linseed oil. Also, Saleh et al. (2013) showed that dietary supplementation of linseed oil decreased plasma total cholesterol and LDL. The obtained trend in the present study came on line with those of Zeweil et al. (2016) who found that serum total lipids, total cholesterol and triglycerides were significantly $(\mathrm{P} \leq 0.01)$ reduced as a result of adding 100 or $200 \mathrm{mg}$ lycopene in growing rabbit diets compared to the control group.

\section{Economic efficiency of feeding diets of linseed oil supplementation:}

Results listed in Table (5) revealed that linseed oil supplementation generally improved feed intake $(\mathrm{Kg} / \mathrm{dam})$ compared to that of the control group. The group received $4.5 \%$ linseed oil recorded the highest value but without significant differences with the other two oil supplementation groups.

Total weight rabbits $(\mathrm{Kg} / \mathrm{dam})$ and average weight rabbits $(\mathrm{Kg} / \mathrm{dam} /$ parity) were the highest $(\mathrm{P} \leq 0.05)$ in the $3.0 \%$ linseed oil supplemented group with lowest $(\mathrm{P} \leq 0.05)$ average of feed consumed (Kg/dam/parity). Average number of parity per dam ranged between 2.4 and 3.0 without significant effect of supplementing linseed oil to dams diets.

Moreover, it seems that, although there is a slight increase in the price of $\mathrm{kg}$ feed with adding oil compared to the control one, the total feed cost was better in the $3.0 \%$ oil group.

The reduction in total feed cost improved net return, economic efficiency and relative economic efficiency for the $3.0 \%$ linseed oil supplemented group compared to that of the control and other two supplemented groups. It is clear that the addition of oil as a source of Omega-3-polyunsaturated fatty acids $(\Omega$ 3-PUFA) improved feeding efficiency by about $17 \%$ and relative economic efficiency by about $34 \%$ compared to the control group. Similar trends recorded by Hamed et al. (2015) by using flaxseed oil at the rate of $2 \%$ with V-line rabbit does.

Generally, Ayyat (2018) reported that feed additives may improve the dietary value in a dose-dependent manner and foster the production of rabbit meat, decrease the perirenal and scapular fat content and improve oxidative stability of rabbit meat. 
Table (5): Economic Efficiency of using linseed oil supplementation in rabbit does diets.

\begin{tabular}{|l|c|c|c|c|}
\hline \multirow{2}{*}{\multicolumn{1}{|c|}{ Parameters }} & \multicolumn{4}{c|}{ Treatments } \\
\cline { 2 - 5 } & Control & $\begin{array}{c}\text { Linseed oil } \\
\mathbf{1 . 5 \%}\end{array}$ & $\begin{array}{c}\text { Linseed } \\
\text { oil 3\% }\end{array}$ & $\begin{array}{c}\text { Linseed } \\
\text { oil 4.5\% }\end{array}$ \\
\hline Total feed intake (Kg/dam) & $34.00^{\mathrm{b}}$ & $36.98^{\mathrm{ab}}$ & $36.37^{\mathrm{ab}}$ & $40.66^{\mathrm{a}}$ \\
\hline Total weight rabbits (Kg/dam) & $11.63^{\mathrm{ab}}$ & $10.78^{\mathrm{b}}$ & $15.74^{\mathrm{a}}$ & $13.07^{\mathrm{ab}}$ \\
\hline Average number of parity/dam & 2.40 & 2.60 & 3.00 & 2.40 \\
\hline Average of feed consumed (Kg/d./parity) & $14.62^{\mathrm{ab}}$ & $14.73^{\mathrm{ab}}$ & $12.12^{\mathrm{b}}$ & $17.59^{\mathrm{a}}$ \\
\hline Average weight rabbits (Kg/d./parity.) & $4.89^{\mathrm{ab}}$ & $4.28^{\mathrm{b}}$ & $5.25^{\mathrm{a}}$ & $5.51^{\mathrm{ab}}$ \\
\hline Price/kg feed (L.E) & 2.54 & 2.59 & 2.66 & 2.71 \\
\hline Total feed cost / parity (L.E) & 37.13 & 38.15 & 32.23 & 47.66 \\
\hline Price/kg live body weight (L.E) & 24 & 24 & 24 & 24 \\
\hline Total return/ parity (L.E) & 117.36 & 102.72 & 126.00 & 132.24 \\
\hline Net return (L.E) & 80.23 & 64.57 & 93.68 & 84.58 \\
\hline Economic efficiency (EE) & 2.16 & 1.69 & 2.9 & 1.77 \\
\hline Relative economic efficiency (REE) & 100 & 78 & 134 & 82 \\
\hline
\end{tabular}

${ }_{\mathrm{a}, \mathrm{b}}$ Means in the same raw bearing different superscript are significantly different $(\mathrm{P} \leq 0.05)$.

1- Net return/ dam (L.E) = Total return/ dam (L.E) - total feed cost/dam (L.E)

2- Economic Efficiency (E.E) = Net return/dam (L.E)/total feed cost/dam (L.E)

3- Relative Economic Efficiency $(\mathrm{REE})=$ E.E/E.E of control x 100.

Conclusively, it could be concluded that supplementing rabbit' does diets with $3.0 \%$ linseed oil recorded the mostly positive results in terms of dams reproductive, productive traits and the studied blood parameters. From economic efficiency point of view, the addition of linseed oil up to $4.5 \%$ as a source of Omega-3-polyunsaturated fatty acids reduced average feed consumption/parity by about $17 \%$ and improved total feed cost/parity (LE), total return/parity (LE) and relative economic efficiency by about $34 \%$ as well.

\section{REFERENCES}

Ayyat, M. S., Al-Sagheer, A.A., Abd El-Latif, K.M. and Khalil, B.A. (2018). Organic selenium, probiotics, and prebiotics effects on growth, blood biochemistry, and carcass traits of growing rabbits during summer and winter seasons. Biol. Trace Elem. Res., pp: 112. https://doi.org/ 10.1007/s12011-018-1293-2

Baucells, M.D.; N. Crespo, A.C.; Barroeta, S.; Lopez Ferrer and M. A. Grashorn (2000). Incorporation of different polyunsaturated fatty acids into eggs. Poultry Science, 79: 51-59. 
Bielanski, P. and Kowalska, D. (2008). Use of linseed oil and antioxidant (vitamin E) in rabbit diets to improve dietetic traits of rabbit meat. In Proceeding 9th World Rabbit Congress, 10-13 June, Verona. Italy. 1319-1323.

Bozkurt, M., Hippenstiel, F., Abdel-Wareth, A.A.A., Kehraus, S., Küçükyilmaz, K., Südekum, K.H. (2014). Effects of selected herbs and essential oils on performance, egg quality and some metabolic activities in laying hens. A review: Eur. Poultry Sci., 78: 15.

Cavani, C., Petracci, M, Trocino, A. and Xiccato, G. (2009). Advances in research on poultry and rabbit meat quality. Ital. J. Anim. Sci., 8 (Suppl 2): 741-750.

DalleZotte, A. and Zs. Szendrö (2011). The role of rabbit meat as functional food. Meat Sci., 88: 319-331.

Dalle Zotte, A. (2002). Perception of rabbit meat quality and major factors influencing the rabbit carcass and meat quality. Review. Liv. Prod. Sci., 75: 11-32.

Duncan, D.B. (1955). Multiple range and multiple F- test. Biometrics, 11: 1- 42.

Eid, Y.; Zeweil, H.; Ahmed, M.H.; Basyony, M. and Maha Farok (2010). Effect of plant source of omega-3 fatty acids and green tea powder on the performance and meat quality of growing rabbits. Egyptian Journal of Rabbit Science, 20 (2): 115-134.

Elkomy, A.E. and El-Speiy, M.E. (2015). Polyunsaturated fatty acids combined with equine chorionic gonadotropin to enhance reproductive performance in aged rabbit does. Italian Journal of Animal Science; Volume 14: 3535-3544.

Hamed, Rawia S., Breakaa, Merfat A. and Said, Hedia EL. (2015). Effect of acacia nilotica leaves extract and flaxseed oil supplementation on milk yield and reproductive performance of rabbit does. Egyptian Poultry Science Journal, 35(2): 627-646.

Hernández, P. and Gondret, F. (2006). Rabbit Meat Quality. In: Maertens L., Coudert P. (Eds.). Recent Advances in Rabbit Sciences. ILVO, Merelbeke, Belgium, 269-290.

Hippenstiel, F., Abdel-Wareth, A.A.A., Kehraus, S. and Südekum, K.H. (2011). Effects of selected herbs and essential oils, and their active components on feed intake and performance of broilers - a review. Arch. Geflügelk., 75 (4): S, 226-234. 
Ikeda, I., Kumamaru, J., Nakatani, N., Sakono, M., Murota, I. and Imaizumi, K. (2001). Reduced hepatic triglyceride secretion in rats fed docosahexaenoic acid rich fish oil suppresses postprandial hypertriglyceridemia. Journal of Nutrition, 131: 1159-1164.

Kemin, Qi A., Chaonan, Fan, Jin Jiang, A., Haiyan Zhu, A., Hong Jiao, A., Qun Meng, A., Richard, B. and Deckelbaum, J. (2008). Omega-3 fatty acid containing diets decrease plasma triglyceride concentrations in mice by reducing endogenous triglyceride synthesis and enhancing the blood clearance of triglyceride rich particles. Clinical Nutrition, 1-7.

Kowalska, D. (2008). Effect of essential unsaturated fatty acids in fish oil on litters and composition of milk of rabbit does. Proc. 9th World Rabbit Congr., Verona, Italy, pp 705-710

Marounek M., A. Dokoupilová, Z. Volek and I. Hoza (2009). Quality of meat and selenium content in tissues of rabbits fed diets supplemented with sodium selenite, selenized yeast and selenized algae. World Rabbit Sci., 17: 207-212.

Mattos, R., Staples, C.R. and Thatcher, W.W. (2000). Effects of dietary fatty acids on reproduction in ruminants. Rev. Reprod., 5: 38-45.

McKeegan, P.J., Sturmey, R.G. (2012). The role of fatty acids in oocyte and early embryo development.Reprod. Fert.Develop., 24: 59-67.

NRC (1977). Nutrient Requirements of Rabbits. National Academic of Scie nce. Washington DC, USA.

Popa, V.M., Gruia, A., Raba, D.N., Dumbrava, $\quad$ D., $\quad$ Moldovan, C., Bordean, D., Mateescu, C. (2012). Fatty acids composition and oil characteristics of linseed (Linum Usitatissimum, L.) from Romania. $J$. Agroal. Proc. Technol., 18: 136-140.

Rodriguez, M., Carro, M.D., Valiente, V., Formoso-Rafferty, N. and Rebollar, P.G. (2017). Effects of dietary fish oil supplementation on performance, meat quality, and cecal fermentation of growing rabbits. Journal of Animal Science, Volume, 95 (8): 3620-3630.

Salama, Maha, F.A. (2011). Studies on the possibility of producing n-3 enriched rabbit meat. M. Sc. Thesis, Fac. Agric. (Saba Basha), Alexandria University, Egypt.

Saleh, A., Ebeid, T.A. and Eid, Y.Z. (2013). The Effect of Dietary Linseed Oil and Organic Selenium on Growth Performance and Muscle Fatty Acids in Growing Rabbits.Pak. Vet. J., 33(4): 450-454. 
SAS (2000). User's Guide: Statistics, Version 8.1. SAS Institute Inc. Cary, NC Simopoulos, A.P. (2000). Human requirement for n-3 polyunsaturated fatty acids. Symposium: role of poultry products in enriching the human diet with n-3 PUFA. Poultry Science, 79: 961-970.

Suraï, P. F. (2002). Selenium in poultry nutrition 2. Reproduction, egg and meat quality and practical applications. World's Poultry Sci. J., 58: 431-450.

Szendrő, Zs.,Gerencsér, Zs., Szabó, A., Fébel, H., Szín, M., Radnai, I., DalleZotte, A., Matics, Zs. (2012). Effect of supplementation of linseed oil, vitamin $\mathrm{E}$ and selenium in diet for growing rabbits on productive and carcass traits. World Rabbit Science Association, Proceedings 10 ${ }^{\text {th }}$ World Rabbit Congress - September, 3-6 (2012), Sharm El-Sheikh-Egypt, 881-885.

Trebušak, Tina.,Levart, Alenka, Voljč, Mojca, Tomažin, urška and Pirman, Tatjana (2011). The effect of linseed oil supplementation on performance, fatty acid composition and oxidative status of rabbits. Acta Argiculturae Slovenica, 98 (2): 119-125.

Zeweil, H.S., Zahran, S.M., Ahmed, M.H., El-El-Gindy, Y. and Shaglouf, W.G.M. (2016). Effects of allicin and lycopene on performance, carcass, hematological profile and antioxidant status of growing rabbits through summer season. Journal of the Advances in Agriculture Research, (Under publication).

Zeng, Z., Zhang, S., Wang, H. and Piao, X. (2015). Essential oil and aromatic plants as feed additives in non-ruminant nutrition: a review. J. Anim. Sci. Biotechnol, 6 (7): 10.

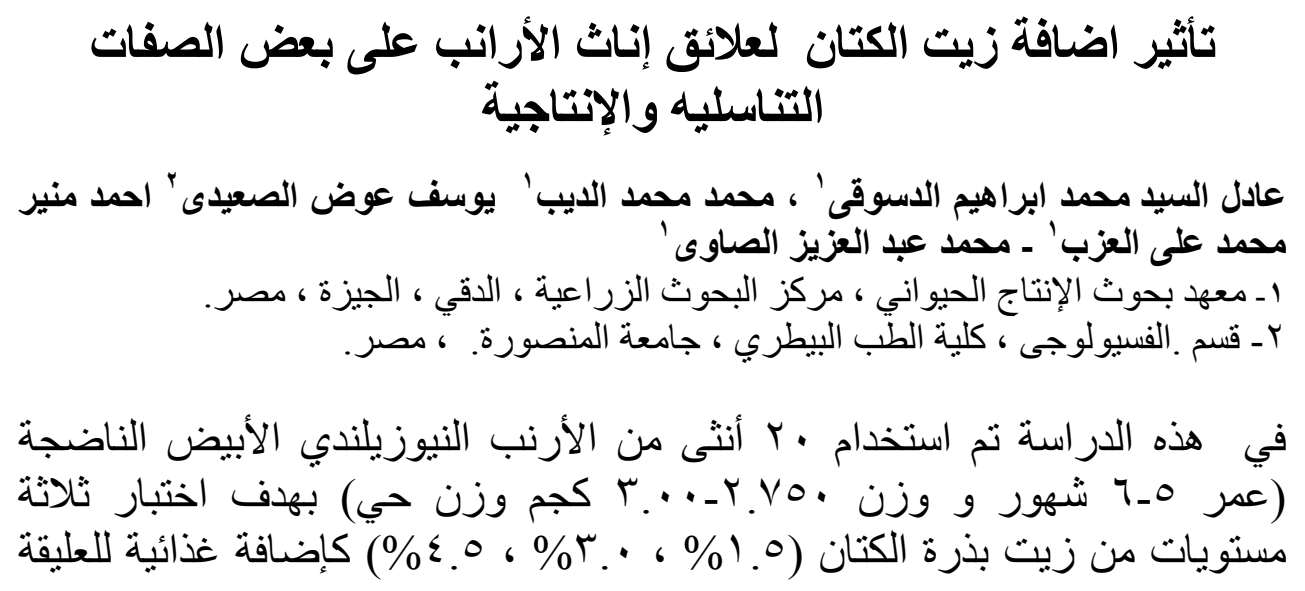


الأساسية لمعرفة تأثير ها على بعض المظاهر التناسلية و الإنتاجية للإناث. كما دُرست

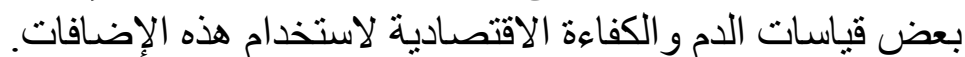

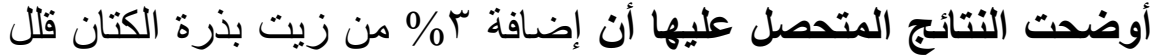

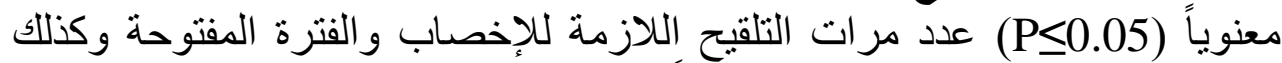

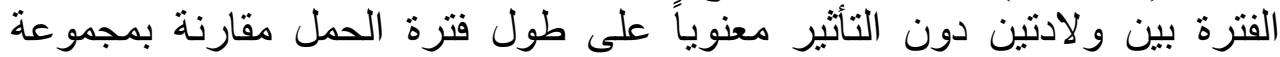

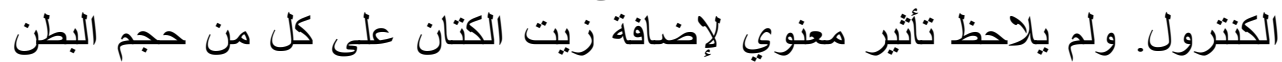

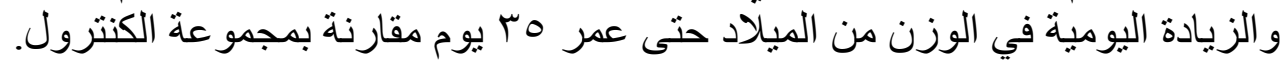

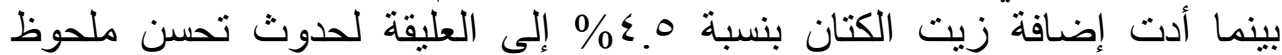

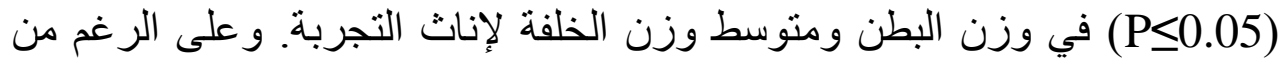

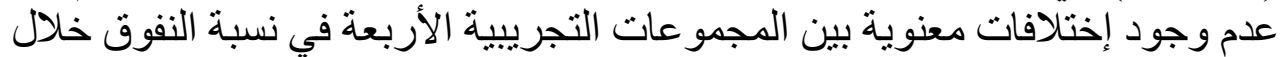

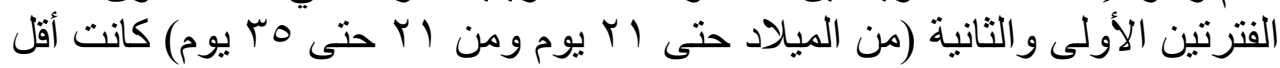

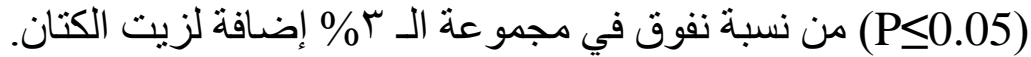

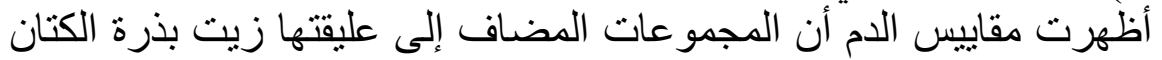

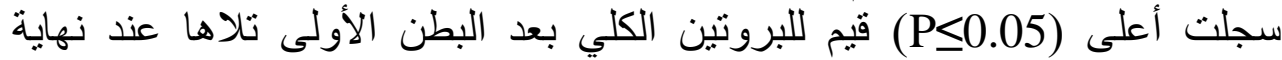

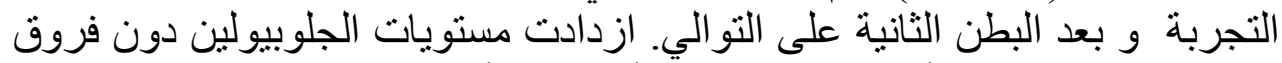

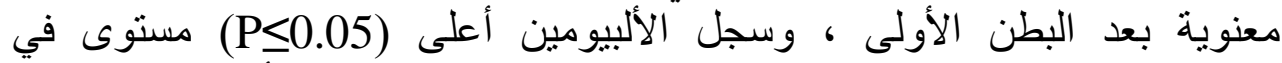

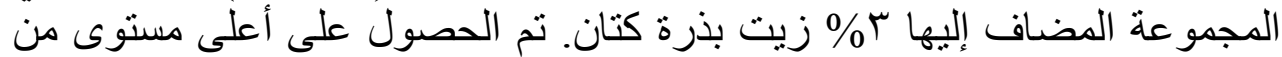

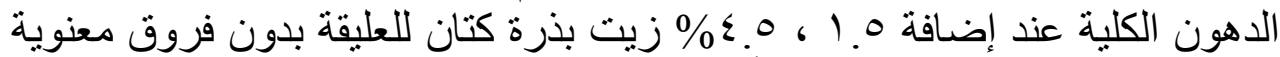

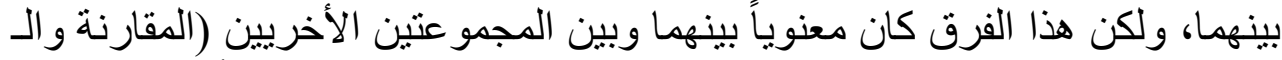

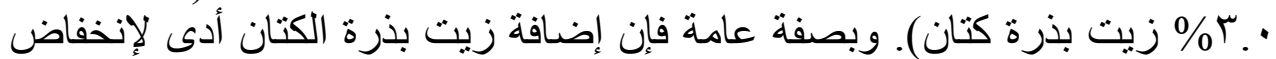

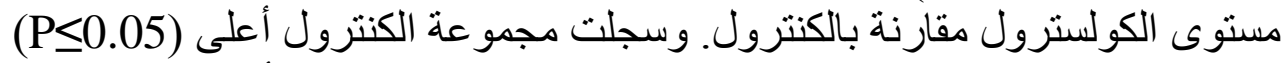

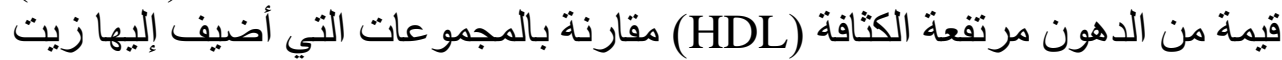

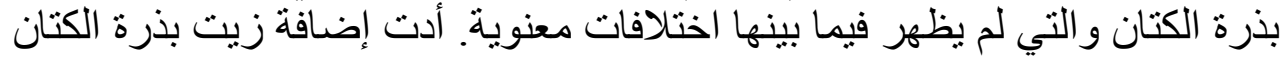

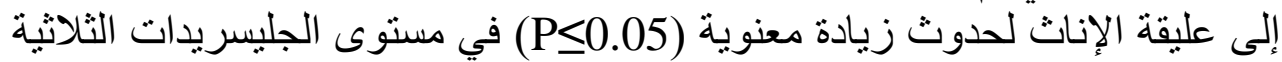

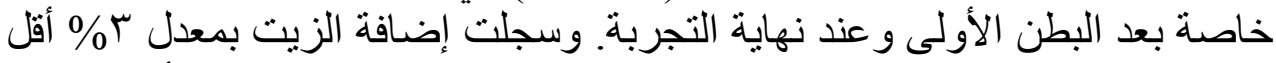
مستوى من الجليسريدات الكلية مقارنة بمجموعتي الزيت الأخرين عند الزية

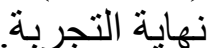

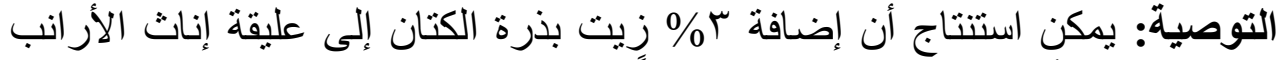

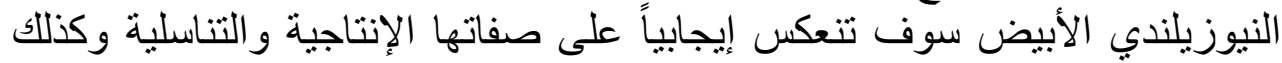

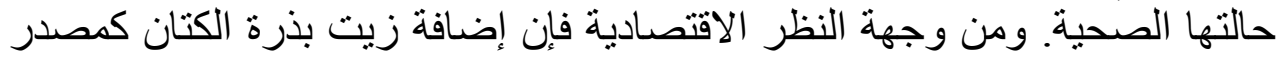

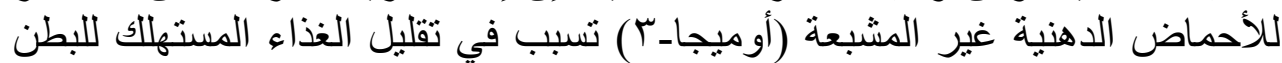

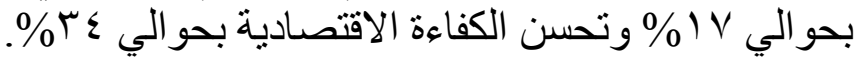

